\title{
El verdadero rol de la bacteriuria asintomática en mujeres jóvenes
}

A prospective study of asymptomatic bacteriuria in sexually active young women. Hooton TM, Scholes $D$, Stapleton AE, et al. $N$ Engl $J$ Med 2000;343:992-997.

\begin{abstract}
Objetivo
Investigar la relación entre la Bacteriuria Asintomática (BA) y el desarrollo de una Infección del tracto urinario (ITU) sintomática.
\end{abstract}

Diseño

Estudio de cohortes prospectivo.

Lugar

Centro de cuidados universitarios y un sistema prepago en Seattle, EE.UU.

\section{Pacientes}

Se incluyeron 796 mujeres sanas, de entre 18 y 40 años, que comenzaban a utilizar un nuevo método anticonceptivo, y no habían tenido más de una ITU en los últimos 12 meses.

\section{Evaluación de factores pronósticos}

Se realizó un cuestionario en la primera visita. Se obtuvo una muestra de orina para buscar piuria y bacteriuria, y una de sangre y saliva para determinar el estado de secretor AB0. Se determinó el genotipo de Escherichia Coli en los urocultivos positivos. Las pacientes llevaban un diario donde registraban los días en que tenían relaciones sexuales, usaban anticonceptivos, tenían síntomas urinarios o tomaban antibióticos.

\section{Medición de los resultados principales}

Los dos centros tuvieron diferentes métodos de seguimiento pero en ambos, a lo largo de 6 meses, se obtuvieron 6 o 9 entrevistas donde se recogieron muestras de orina para buscar piuria y bacteriuria, y se revisó la adherencia al registro diario.

\section{Resultados principales}

La prevalencia de piuria fue de $24 \%$ en aquellas mujeres con muestras de orina con más de $10^{5}$ unidades formadoras (UFC) colonias, y $3.6 \%$ en las muestras con menos de $10^{5}$ UFC.

La prevalencia de BAfue de $5 \%$ y $6 \%$ de los pacientes en los dos centros, siendo el germen más frecuente la E. Coli $(77$ y $80 \%$ respectivamente). La incidencia de BA fue 0.39 y 0.53 episodios por persona por año. Aproximadamente una de cada 5 mujeres presentó al menos un episodio de BA a lo largo del estudio. Las mujeres con cultivos negativos tuvieron solo un $1 \%$ de ITUs a la semana siguiente, mientras que en las pacientes con BAel riesgo de ITU en la semana posterior fue del $8 \%(p<0.001)$; y si además tenían piuria el riesgo de ITU fue del $15 \%$. No se identificó un genotipo de E. Coli con mayor tendencia que otro a producir ITU sintomática. Como factores de riesgo, en el análisis multivariado* solo el uso reciente de diafragma con espermicida y las relaciones sexuales recientes estuvieron asociadas significativamente a BA en los dos grupos RR 1.6 (IC95\% 1.4-1.9) y 1.3 (IC 95\% 1.1-1.4) respectivamente.

\section{Conclusiones}

La BA en esta población es frecuente, pero raramente persiste. Aún así es un predictor de ITU sintomática, y no se conocen las variables que determinan que un BA se transforme o no en ITU o no.

Se halló, en concordancia con estudios anteriores, la correlación entre las relaciones sexuales y el uso de diafragma con la incidencia de BA.

Fuente de financiamiento: Instituto Nacional de Diabetes y Enfermedades Digestivas y Renales, EE.UU.

\section{Comentario}

La sencillez, bajo costo y confiabilidad del urocultivo para detectar bacteriuria ha generado desde hace muchos años un gran interés por encontrarle la utilidad como práctica preventiva. Hay clara evidencia que en las mujeres embarazadas la bacteriuria asintomática (BA) acarrea un riesgo aumentado de pielonefritis, parto pretérmino, niños con bajo peso al nacer y aumento de la mortalidad perinatal. Hay evidencia de estudios clínicos aleatorizados y meta-análisis que demuestran que la detección y tratamiento de BApuede disminuir la incidencia de estos eventos ${ }^{1}$. En ciertos grupos de alto riesgo, como son los pacientes que se van a realizar un estudio invasivo de las vías urinarias, los pacientes que recientemente han recibido un trasplante renal, o los que cursan una neutropenia profunda se ha demostrado claramente el beneficio de la búsqueda y tratamiento de la BA con el urocultivo como herramienta. Hay controversia sobre la importancia de la BA en los pacientes diabéticos?2.

Las infecciones del tracto urinario (ITU) son la primer causa de bacteriemia en ancianos, y estos episodios tienen un $10-30 \%$ de mortalidad. Sin embargo los estudios clínicos aleatorizados que evaluaron la estrategia de búsqueda y tratamiento de la bacteriuria asintomática no pudieron demostrar diferencias de mor- bimortalidad entre los dos grupos, y sí detectaron aumento de efectos adversos a los antibióticos y de la resistencia bacteriana a los mismos ${ }^{3}$.

En los niños las ITU son causa de cicatrices renales que pueden llevar a hipertensión arterial o insuficiencia renal; esto sucede generalmente en los niños antes de los 4 o 5 años de edad. Los estudios realizados hasta el momento no han logrado demostrar un beneficio del rastreo de BA. Además, en esta edad es mucho más complejo obtener la muestra por una técnica no invasiva, y su sensibilidad y especificidad no está del todo clara en un escenario real, donde es muy frecuente la contaminación por errores en la obtención y manipulación de la muestra.

Con respecto al estudio que estamos comentando, en un editorial en el mismo número del "New Enggland", la especialista en el tema $L$ Nicolle refiere que pese a ser este un grupo de pacientes en el que la BA es un trastorno común y benigno, es muy importante conocer cuales son las variables de los pacientes y de los microorganismos que determinan que una infección se transforme en sintomática ${ }^{4}$. Esto permitirá el desarrollo de nuevas estrategias para el tratamiento que superen los problemas actuales de generación de resistencia bacteriana.

\section{Dr. Alejandro Lopez Osornio [ Unidad de Medicina Familiar y Preventiva. Hospital Italiano de Buenos Aires ]}

Referencias

1. Romero R, Oyarzun E, Mazor M, et al: Meta-analysis of the relationship between asymptomatic bacteriuria and preterm delivery/low birth wight. Obstet Gynecol 1989;73:576-582 2. Grupta K, Scholes D, Stamm WE. Increasing prevalence of antimicrobial resistance among uropatogens 3) causing acute uncomplicated cystitis in women. JAMA199;281:736-738 3. Nicolle LE. Asymptomatic bacteriuria in the elderly. Infect Dis Clin North Am 1997;11:647-662

4. Nicolle LE. Asymptomatic bacteriuria, important or not? N Engl J Med 2000;343: 1037-1039 